\title{
Decoloniality, Spanish and Latin American Studies in Australian Universities: ¿es un mundo ch'ixi posible?
}

\author{
Danielle H. Heinrichs a * \\ ${ }^{a}$ School of Education, University of Queensland, Brisbane, Australia \\ d.jeffery@uq.net.edu \\ https://orcid.org/0000-0002-6730-686X
}

\section{Notes on contributors}

Danielle Jeffery is a $\mathrm{PhD}$ Candidate in the School of Education at the University of Queensland, Australia. Her research interests include decoloniality, discourse studies, Spanish and Latin American studies and heritage languages. As part of her doctoral studies, Danielle examines the intersection of languaging, decoloniality and social media in Spanish as a world language education. She is trained in Spanish and Latin American studies and German and has experience lecturing and teaching communication, sociology and Indigenous studies.

Word Count: 11502 words 


\section{Introduction}

The notion of $c h$ 'ixi, like many others (allqa, ayni), reflects the Aymara idea of something that is and is not at the same time. It is the logic of the included third. A ch'ixi color gray is white but is not white at the same time; it is both white and its opposite, black. The ch'ixi stone, therefore, is hidden in the bosom of mythical animals like the serpent, the lizard, the spider, or the frog; ch'ixi animals belong to time immemorial, to jaya mara, aymara, to times of differentiation, when animals spoke with humans. The potential of undifferentiation is what joins opposites. $^{28}$

The notion of ch'ixi seems unclear in the current context for world languages in Australia given the universalising goals of neoliberalism to which the education system is subjected. In a similar way to $c h$ 'ixi, the Australian language education context has been described as an oxymoron: it simultaneously proclaims to operate in a multicultural nation while increasingly normalising monolingualism ${ }^{1}$ by promoting English as a global language ${ }^{2}$. This is increasingly evident to critical eyes familiar with the ways in which neoliberalism and modernity force world ${ }^{3}$ languages to compete not only in and amongst themselves but also against other disciplines for resources, student numbers and respect.

I began my career in world languages education naïvely unaware of the ways in which higher education institutions, curricula, funding, grants, student enrolments, staffing decisions and policy mandates were founded and funded through capitalist profits made possible because of the exploitation of Indigenous lands and peoples ${ }^{84}$ and the erasure of their knowledges ${ }^{4}$. However, recent global and national movements against coloniality in Western universities, such as the "Rhodes Must Fall, Leopold Must Fall, Why is My Curriculum White?, Why Isn't My Professor Black?, Dismantling the Masters House, Liberate my Degree, Silence Sam"25, have demanded that we take stock of the ways coloniality continues to operate within higher education institutes and look for ways to address this ${ }^{3 ; 26}$. In the Australian context, public debate around the need to decolonise higher education has recently been tied to calls for the removal of a statue of Lachlan Macquarie in Sydney ${ }^{29}$ and the controversy surrounding the offering of a degree in Western Civilisation based on 'a narrative of Western civilisation worth celebrating' ${ }^{16}$. These critiques of the coloniality in higher education have emerged from a number of countries $^{52 ; 74}$ indicating the globality of the impetus towards decolonising practices in this space and inspiring researchers and educators to (re)examine educational policy, practice and pedagogy. 
My experiences teaching and learning Spanish in Australia and abroad over the past twelve years have also revealed similar concerns due to the ways in which Spanish as world language has played into neoliberalism and coloniality. This has been accomplished by adhering to a strict conception of grammar guided by linguistic purity when drilling students on verb conjugations, direct and indirect object pronouns and the uses of the dreaded subjunctive mood. In addition, institutions located in Spain such as the Real Academia Española (RAE) ${ }^{4}$ continue to promote colonial linguistics by regulating the correct usage of Spanish and extending their reach globally through teacher training and proficiency certification. This invention of Spanish as a world language leads to native-speakerism ${ }^{5}$ which has been described as prejudice towards non-native speakers of English ${ }^{6}$ or other dominant languages ${ }^{7}$ which fixes particular speakers to particular types of imagined languages ${ }^{62}$. How many times has my use of marido instead of esposo to refer to my husband evoked mocking laughter from native Spanish-speakers; when I consider my own use of Spanish, how many times have I, the blonde-haired, blue-eyed, gringa-monster-imposter, questioned grammatically incorrect examples of Spanish(es) by native-speakers? The line between the native-speaker and the non-native speaker begins to blur as does the finger-pointing to those at fault for its construction ${ }^{8}$. Such dichotomising colonial practices in Spanish as a world language education in Australia have been largely ignored ${ }^{9}$ despite being situated between two colonial contexts: Australia and AbyaYala ${ }^{10}$ and the murmurings of Indigenous languages on these lands.

I have met and worked with academics from Spanish and Latin American studies departments around Australia. Many are engaged with decoloniality and moving beyond colonial linguistics which fosters notions of ideal learners and grammatical perfection for Spanish as a world language. However, I am uncomfortable with the ways in which institutions require strict adherence to colonial linguistics and segregationist logics in one of the main promotional materials for Spanish and Latin American studies: course descriptions. I have chosen to focus on course descriptions given the ease of access for enrolled and non-enrolled students and the acknowledgement of the importance of course descriptions for course selection ${ }^{11}$. In focusing on the course description, my analysis seeks to trouble the lack of attentiveness regarding how language education is marketed by universities in the Australian context ${ }^{12}$. Given their reach, I am left wondering how (if at all possible) Spanish and Latin American studies departments visibilise decoloniality in their course offerings through course descriptions. This also raises questions about the underlying ethic guiding Spanish as a world language education in Australia: To 
whom/what is it accountable? What type of languaging is valued/privileged and why? How are these ethical response-abilities embodied by course offerings in Spanish and Latin American studies departments in Australia in relation to this underlying ethic? In other words, ¿es un mundo ch ixi possible? Is a ch'ixi world possible?

Therefore, this paper takes a decolonial turn to examine the course descriptions from nineteen universities in Australia that offer units as part of a Spanish and Latin American studies minor or major. I selected universities if they offered a minor and/or major in Spanish and Latin American studies, or similarly named program. As an example, The University of Technology, Sydney offers a sub-major in Spanish Language and Culture. This resulted in nineteen universities being included, and a total of 222 courses listed on offer in 2019 at undergraduate, postgraduate and honours levels were analysed from these universities. I excluded courses if they did not pertain to the teaching of Spanish language and/or Spanish and Latin American cultures or histories explicitly. For example, a number of courses in first year linguistics, second-language acquisition or general European history were included as electives in some Spanish and Latin American studies minors/majors but did not have any specific reference to Spanish, Spain and/or Latin America in the course description and were, therefore, excluded. Courses were also excluded if they appeared on the university website in 2019 but were not listed as on offer in 2019. Once the relevant courses had been identified, I drew on decolonial theories to look for the presence of related themes in the course descriptions. These were manually coded with relevant decolonial themes before being sorted into three prominent categories: historical acceptance, language diversity, and gender and sexuality. I then examined the examples in each of the three prominent categories for patterns in the discursive markers such as textual synonymy before attempting a further interpretation of the examples guided by decolonial theory.

The decolonial turn I attempt in my interpretation and reading here tries to understand how Spanish and Latin American studies departments visibilise and preference ethico-onto-epistemological ${ }^{13}$ response-abilities to decoloniality from alternative and diffractive perspectives. In this project, ethico-onto-epistemological response-abilities are taken to be the inseparability of ethics (morals, values, what matters matter), ontology (ways of being) and epistemology (ways of knowing) (see Table 1). However, the conceptualization of ontology I draw on here differs from the classical definition concentrating on the essence of being or existence; instead, I refer to ontology as the relationalities between boundaryless, entangled phenomena drawing on the work 
of Karan Barad ${ }^{14}$, Anders Burman ${ }^{17}$ and Humberto Maturana ${ }^{15}$. In other words, the ontology I refer to underscores the diffractive patterns emerging from entwined objects. Such an understanding of ontology resists the separation of reality into material, discursive or social phenomena interacting by way of homology and turns towards the multiplicity of intra-actions performed by all phenomena. This allows for a turn towards a relational ontology in which potentially antagonistic positionings are drawn into understanding and becoming, deconstructing and constructing to move beyond 'philosophical deadlocks' ${ }^{75}$. Burman describes this as ontological disobedience and chi'ixi practice whereby subalternised and Othered knowledges exist side by side with dominant knowledges rather than in isolation. Moreover, he adds that "to speak of reality as ch'ixi or of a ch'ixi ontology is, then, to underscore the miscellaneous nature of reality and the coexistence without complete fusion of elements from, as it were, different realities in one and the same lifeworld"18.

Table 1: Ethico-onto-epistemology

\begin{tabular}{|c|c|c|c|}
\hline Ethico- & onto- & epistemological & response-abilities \\
\hline $\begin{array}{l}\text { Values } \\
\text { Morals } \\
\text { What matters } \\
\text { matters }^{13}\end{array}$ & $\begin{array}{l}\text { Being as the } \\
\text { inseparability of } \\
\text { phenomena/objects } \\
\text { (diffraction } \\
\text { patterns) }^{16} \\
\text { Language as } \\
\text { phenomena of }_{\text {human existence }^{17}}\end{array}$ & Ways of knowing & $\begin{array}{l}\text { A praxis of care and } \\
\text { response...in an } \\
\text { ongoing } \\
\text { multispecies } \\
\text { worlding; } \\
\text { collective knowing } \\
\text { and doing; an } \\
\text { ecology } \\
\text { practices }{ }^{18} \\
\text { mutual responses } \\
\text { attending to power } \\
\text { imbalances }\end{array}$ \\
\hline
\end{tabular}

Within the course descriptions, examples of ethico-onto-epistemological response-abilities to decoloniality are taken to include: reference to decolonial theory and concepts (e.g. geopolitics, languaging, cosmovision, biocentrism, visibility of women, pluriversality), and the presence of Spanish(es) and Indigenous languages of AbyaYala. I suggest that these themes of decoloniality have been/are marginalised under the 
conditions of coloniality ${ }^{19: 56}$ such as native-speakerism, colonial linguistics, the invention of 'Spanish', languages as discrete phenomena and idealised bilingualism. Given that Spanish and Latin American studies departments in universities in Australia operate under these conditions, this paper questions what it might look like when these departments visibilise these themes in their course descriptions. This paper offers a decolonial critical discourse analysis of these texts, not to centre only knowledges of AbyaYala, but rather to showcase the validity of multiple and entangled knowledges and how this can be done even within institutional constraints as an example of a possible ch'ixi world.

\section{Contextualising Spanish and Latin American Studies departments in}

\section{Australian universities}

Of the forty universities in Australia, nineteen offer Spanish (or Spanish and Latin American studies) on-campus, most often as a major or minor in a Bachelor of Arts or Bachelor of International Studies degree although it is becoming more common for universities to offer this as an elective within a broader range of degrees. The number of courses varies widely between universities with some offering as few as 5 courses over the first and second year and others offering up to 24 including units at honours and postgraduate level. The universities with the broadest offerings are in the most populous cities namely Sydney, Melbourne and Brisbane.

Within these universities, it is often taken for granted that intercultural dialogue ${ }^{32}$, perhaps under the guise of transculturality, global awareness or cross-cultural learning ${ }^{51}$, is a natural outcome of world languages. While Spanish and Latin American studies departments in Australian universities face institutional pressure to capitalise on the universalising and neutralising discourses of interculturality ${ }^{5}$, it is these same discourses which marginalised these departments. To illustrate, language departments are pressured to position world language courses as 'add-ons' that provide opportunities for interactions between cultures to ensure survival given high attrition rates ${ }^{6}$. This in turn marginalises language departments by devaluing them whereby courses are seen as 'extra units' rather than majors worthy of dedicated study. Further, language departments compete with increasing numbers of international students seeking to learn English, not other world languages. Hence, Australian universities entangle Spanish and Latin American studies departments in the 'colonial matrix of power' ${ }^{20}$ in which they must rely on competitive 
and marketable versions of their courses and discourses relating to the 'fun' of learning a language to survive.

The Australian context increasingly perceives Spanish as a world language as 'elitist' ${ }^{\text {'1 }}$ which assists in increasing enrolment numbers, but it also values a particular type of language learner: university-educated students from upper-middle-class backgrounds or native-speakers ${ }^{22}$. As a result, a hierarchy of language speakers emerges within Spanish and Latin American studies departments that devalues the plurality of Spanish(es) and the diversity of its speakers and learners. Moreover, such an insecure position leaves limited opportunity for critical or radical pedagogies that disrupt dominant approaches regarding the presumed innate presence of multicultural values in world language education including Spanish. At the same time, the United Nations declared 2019 the International Year of Indigenous Languages amidst concern for the declining numbers and the marginalisation of such languages worldwide, including in Australia and AbyaYala. Furthermore, these concerns for Indigenous languages are associated with linguicide ${ }^{23}$ and epistemicide ${ }^{24}$ for the ways in which they mask other ways of knowing, doing and being with dominant languages such as English and Spanish. This places Spanish and Latin American studies departments in Australian universities in a complex situation: one in which they must maintain their position by playing into the capitalist discourse(s) driving coloniality while wondering how to respond to the marginalised Indigenous languages they are geo-politically entangled with. Hence, Spanish and Latin American studies departments are accountable to neo-liberal and decolonial concerns from national government and global non-government organisations. This context again raises questions of ethical response-ability: in the search for un mundo ch'ixi, to whom/what should Spanish and Latin American studies be accountable?

In relation to some of these concerns about response-ability, the attempts by Spanish and Latin American studies departments in Australia to alter their pedagogical approaches by including content and language integrated learning (CLIL), bilingual/immersion programs ${ }^{25}$ and exchange opportunities to expose students to local and Indigenous cultures can be considered. Although these approaches might attempt to reconcile the complex situation of Spanish and Latin American studies departments in Australia, they may not question, challenge or disrupt the underlying ethico-ontoepistemology of these departments and the courses they offer. Rather than addressing this issue from a deficit perspective in search of how these departments foster coloniality, this paper raises questions about how such departments are visibilising decoloniality in their 
course descriptions. Decolonial theory offers a lens for considering how these course descriptions provide a generative tension which privileges a multiplicity of voices. In other words, decolonial theory offers an alternative ethico-onto-epistemological response attentive to what Aymaran sociologist Silvia Rivera Cusicanqui describes as un mundo ch 'ixi $^{26}$ : a world which 'combines the Indian world and its opposite without ever mixing them ${ }^{27}$ and 'expresses the parallel coexistence of multiple cultural differences that do not extinguish but instead antagonize and complement each other' ${ }^{28}$.

\section{Decoloniality as an ethico-onto-epistemological response-ability}

The terms decolonial and decoloniality have become academic buzz words in much recent "post" scholarship and it is worth tracing their intellectual genealogy in becoming "decolonial theory". However, the alternative thinking and challenge to dominant epistemologies present in decolonial theory has emerged from a number of prominent thinkers over the past century from various geographical and disciplinary backgrounds. That is to say, it might be in vogue now, but the concept is not necessarily new.

The intellectual genealogy of decolonial theory arguably begins with Paulo Freire, Frantz Fanon and Albert Memmi in their discussions of mind-colonising structures stemming from Brazil, France and French Tunisia respectively. Concern for the cultural implications of colonisation in postcolonial studies by diasporic scholars from the Middle East and South Asia such as Edward W. Said, Homi K. Bhabha and Gayatri C. Spivak have also addressed issues of marginalisation and subalternity. More recently, Walter Mignolo and Aníbal Quijano have continued to challenge dominant epistemic frameworks with the conception of decolonial theory from a Latin American perspective by positing decoloniality as an antecedent to coloniality, itself predicated on modernity, resulting in the 'colonial matrix of power'. They explain the colonial matrix of power as the ongoing processes of coloniality that emerged via modernity which subjugate and marginalise non-Western/Eurocentric forms of knowing, doing and being in pursuit of colonial power, capital and legitimacy ${ }^{29}$. This subjugation is marked by hierarchies based on race, gender, language, spirituality and heteropatriarchy ${ }^{71}$. Decolonial thought rejects the teleological endings associated with colonisation, instead seeing coloniality as everpresent via the colonial matrix of power. Internal colonialism has also been used to explain the ways in which coloniality becomes ingrained in colonised peoples causing inter-ethnic conflicts ${ }^{30}$. 
Decolonial thought is further characterised by critiques of the universalising, essentialising and anthropocentric doctrines of dominant, Western thought that invisibilise local and Indigenous knowledges ${ }^{31}$. Nelson-Maldonado Torres emphasises the violence, slavery and genocidal practices used by colonisers for labour market control starting in the Caribbean ${ }^{32}$ before expanding into what has been called the myth of Latin America $^{33}$. The expendability of not only human life, but land, knowledge and language are understood as a part of coloniality/modernity. While it is possible to read these critiques of coloniality as calls to abandon colonial thought, Castro-Gómez ${ }^{20}$ asserts that decolonising the academy is about an integrative approach to thought which brings together a broader array of knowledges including those from marginalised and Other perspectives.

I also draw further attention to Bolivian Aymara sociologist Silvia Rivera Cusicanqui to re-politicise decolonial theory by engaging with the social sciences of the Andean region in a way that Cusicanqui claims some canonical decolonial writers may not $^{34}$ despite their recognition of the importance of situatedness and local knowledges ${ }^{35}$. Cusicanqui highlights the notion of ch'ixi, an Aymara term denoting the colour of juxtaposition that values the potential of indifference that joins two opposing phenomena such as the Indian world and its opposite without succumbing to the need to mix them ${ }^{36}$. She calls for recognition of double and contentious ancestries in ways that allow for Indigenous modernity to be recognised through creative dialogue by exchanging knowledges, aesthetics and ethics. This suggests a pluriversal understanding of the world in contrast to the hegemonic universalisms perpetuated by coloniality. Her thinking, situated in the periphery both geographically and epistemologically even within the corpus of decolonial thought, showcases other important aspects of decoloniality: border thinking and gender. Gloria Anzaldúa writes of the borderlands, not only physical but psychological, sexual and spiritual, as a site of resistance to the colonial matrix of power $^{37}$. This peripheral thinking, knowing, doing and being is seen in decolonial thought as a possible tool for considering ways of delinking from coloniality.

Decolonial thought is not without criticism; there has been concern it has been canonised and espoused primarily by thinkers now situated in the global North ${ }^{38}$, generating binarisms between knowledge from the North and other locations, and overemphasising the power of so-called modern epistemologies ${ }^{39}$. Moreover, the positioning of particular knowledges as modern also risks ignoring how Indigenous epistemologies are also modern. 'It is indeed important to avoid implying that the 
indigenous is "not modern"; yet it is also crucial to understand in what ways it is more than that ${ }^{40}$. With these criticisms in mind, decolonial theory offers a critical and alternative lens with which to examine the course descriptions in this paper. Thus, these critiques centre the possibility of un mundo ch'ixi by highlighting the notion of what is and what is not as it refers to 'modern' in a decolonial theoretical framework.

\section{Turning methodology towards decoloniality}

To analyse the course descriptions, I employ a decolonial critical discourse analysis drawing on Latin American perspectives. The field of critical discourse analysis emerged from Europe and North America as a multidisciplinary tool for analysing discursive practices created and sustained in everyday life and social institutions ${ }^{41}$. It is primarily concerned with examining the role of power in the language of text and talk. Critical discourse studies posit language as dynamic rather than static $^{42}$ subject to sociocultural expectations, institutional $\operatorname{control}^{43}$ and dominant ideologies ${ }^{44}$. Furthermore, critical discourse studies emphasise the importance of situated context for understanding rhetoric ${ }^{45}$ and suggests that genre is a semiotic reflection of this context ${ }^{46}$. In the present study, course descriptions exemplify the genre.

Despite some commonalities across critical discourse studies projects, Van Dijk warns that critical discourse analysis is more than a method and rather 'a social movement of socio-politically committed discourse analysts using many different methods of analysis, for example, in order to show how exactly discourse is involved in the (re)production of power abuse and its consequences for social inequality ${ }^{47}$. However, Rebecca Rogers acknowledges that monocultural epistemologies have been privileged in critical discourse analysis given its Northern Atlantic trajectory ${ }^{48}$. She argues that this is of concern for educational studies utilising critical discourse analysis as they often seek to promote diversity and equity. From a Latin American perspective, scholars as Laura Pardo ${ }^{76}$, Neyla Pardo Abril ${ }^{1 ; 2}$ and Adriana Bolívar ${ }^{14}$ emphasise the need for citation practices to acknowledge the contributions of scholars from the South or risk remaining complicit in the coloniality of knowledge production in discourse studies. In a recent discussion about the direction of critical discourse studies in Latin America, Mendizábal ${ }^{67}$ emphasises the turn towards 'undisciplinary' practices that work with Indigenous epistemologies such as those discussed by Silvia Rivera Cusicanqui.

Hence, this paper responds to recent calls for critical discourse analysis to move beyond conservative canons of thought to a situated and potentially innovative form of 
critical discourse analysis that draws on the thinking of marginalised voices such as Latin American and decolonial thinkers ${ }^{49}$. Consequently, this paper introduces epistemologies of the South as one of the different methods available to discourse analysts with the purpose of decolonising critical discourse analysis. However, Resende ${ }^{50}$ asserts that decolonising critical discourse analysis does not involve rejecting what has been created in the Global North but rather incorporating a 'decolonial spin in understanding the axis of power, knowledge and being'. She describes this decolonial spin in decolonial critical discourse analysis as one which abandons hermetic jargon and addresses the intersectionality of the social structures of patriarchy, capitalism, ethnicity, sexuality, gender, class and coloniality ${ }^{51}$.

Therefore, although this paper follows the traditional three-dimensional conventions in critical discourse analysis: content and topic analysis, discursive strategies and linguistic means ${ }^{52}$ it attempts to do decolonial critical discourse analysis differently by incorporating decolonial perspectives. In order to determine the content and topics of discourse, I examined the course descriptions searching for examples that could be considered themes pertinent to decoloniality. Terms and phrases from the course descriptions in the form of quotes were then extracted as examples of the following content and topics: historical acceptance, language diversity, and gender and sexuality inspired by the call to take into account local and past contexts and sitations ${ }^{15}$. These themes were theoretically motivated by decolonial literature, particularly those from Latin American perspectives. Following the classification of themes I saw as related to the decolonial literature, I interpreted the discursive strategies - 'systematic ways of using language ${ }^{53}$ - present in these examples from a decolonial perspective as well as their linguistic means. My analysis highlighted the various ways in which Spanish and Latin American studies departments are attempting to subvert hegemonic practices in colonial institutions through discourse in their course descriptions as possible answers to the questions raised earlier which I remind us of once again: To whom/what are Spanish and Latin American studies departments accountable? What type of languaging do they value/privilege and why? How are these ethical response-abilities embodied by course offerings in Spanish and Latin American studies departments in Australia in relation to this underlying ethic? In other words, ¿es un mundo ch 'ixi possible? Is a ch'ixi world possible? 


\section{Theme One: Historical acceptance}

The notion of historical acceptance ${ }^{54}$ can be described as the understanding and accepting of multiple truths about the colonial past, colonial wrongdoings and their impacts. It involves acknowledging the fabrications of past lives through settler colonialism: the intentional home-making on land where earth, water and air can be made a source of capital $^{55}$. In other words, settler colonialism is seen as not a singular event in the history of coloniality, but an on-going, continually reasserted form of colonial violence. CDA scholars of Latin America also consistently emphasise the need for the method to contextualise analyses in such locally situated histories ${ }^{15 ; 67}$.

Decolonial thinkers have further critiqued colonial conceptions of history for positioning marginalised peoples as those without history ${ }^{56}$. It is also claimed that coloniality presupposes a linear ${ }^{57}$ macro-history which presumes capitalism, modernity, rationality and civility as natural outcomes in the history of a nation ${ }^{58}$. In addition, Walsh and Mignolo ${ }^{59}$ trace the birth of Latin American history to the naming of the continent of AbyaYala in European terms as part of a process that sought to homogenise, unify and erase existing cultural, spiritual, territorial and economic foundations through the linguicide and epistemicide Given this contention in relation to temporality, this raises a question not about to whom Spanish as a world language in Australia is response-able but to when and which of these conceptualisations of temporality is visibilised in the course descriptions?

The invention of America, as a continent waiting to be discovered, is one of the ways in which Mignolo ${ }^{60}$ argues that European history subsumed Indigenous peoples into a peripheral nation of the West. America and its land were transformed into sites of history and locations that amassed history ${ }^{61}$ from the point of European contact but not before. This geo-political construction of Latin America as a region with a universal identity thereby facilitated historical amnesia by ignoring all that came before coloniality/modernity. Thus, in analysing the course descriptions from Spanish and Latin American studies departments, I sought examples of content highlighting the ch'ixi notion of mixing opposites as examples of temporal response-ability.

The idea of Latin America as a colonial construct with a contentious history is visibilised in the lexical items and the multiple uses of hyponyms related to the hypernym 'historical' (see Figure 1). The collective repetition in multiple course descriptions of cohyponyms of 'historical' in the genre of Spanish and Latin American studies course descriptions work to 'generate new meanings by generating new combinations of 
elements of semiotic systems' also known as the process of texturing ${ }^{62}$. The course descriptions present a version of history that acknowledges the invention of Latin America. They see the source of this invention since the advent of modernity stemming from Europe whilst simultaneously noting the increasing influence of the United States under the guise of globalisation through the inclusion of hyponyms such as the darker side of European Modernity ${ }^{91}$, globalising and neoliberal trends ${ }^{60}$. On the other hand, hyponyms of resistance and Independence (re)present Latin American history as both contemporary and archaic, foregrounding a retaking of historicity ${ }^{63}$. This points to a shift in the ethico-onto-epistemological bases of Spanish and Latin American studies in Australian universities towards a historical approach which makes room for double origins that value:

the parallel coexistence of multiple cultural differences that do not extinguish but instead antagonize and complement each other. Each one reproduces itself from the depths of the past and relates to others in a contentious way ${ }^{64}$

Table 2. Excerpts including (co)-hyponyms of 'historical' (hypernym) appearing in online course descriptions from Spanish and Latin American studies departments in seven of the nineteen Australian universities.

\begin{tabular}{|c|c|c|c|}
\hline \multicolumn{4}{|c|}{ Historical } \\
\hline imagined & colonial & Modernity & resistance \\
\hline $\begin{array}{l}\text { This module will analyse } \\
\text { how Argentina has been } \\
\text { imagined and invented within } \\
\text { and without. }{ }^{97} \\
\text {... students will gain a deeper } \\
\text { appreciation and } \\
\text { understanding by contrasting } \\
\text { how Latin Americans and } \\
\text { those outside of it (namely } \\
\text { Europe and the USA) have } \\
\text { constructed their imagination } \\
\text { of Latin America in the } 20 \text { th } \\
\text { Century. } \\
\\
\text {..first, that Latin American } \\
\text { thought has been } \text { constructed } \\
\text { as a marginal paradigm in the } \\
\text { symbolic space of Western } \\
\text { culture. }{ }^{98} \\
\text { This Unit provides a platform } \\
\text { for the study of Spanish and } \\
\text { Latin American societies } \\
\text { through a critical } \\
\text { examination of the concept } \\
\text { of citizenship and its cultural }\end{array}$ & $\begin{array}{l}\text { Europe }{ }^{97} \\
\text { USA }{ }^{97} \\
\text { Culinary identities in Spain } \\
\text { and Peru will also be } \\
\text { examined in the context of } \\
\text { regional rivalries, regional } \\
\text { integration, post-colonial } \\
\text { legacies and dictatorial } \\
\text { rule. } \\
{ }^{87} \\
\text { Historical topics that may be } \\
\text { covered include the } \\
\text { colonisation of Latin } \\
\text { American. } \\
\text { A8 } \\
\text { In this historically based } \\
\text { Latin American Studies } \\
\text { subject, students address the } \\
\text { discovery and conquest of } \\
\text { the Americas as a turning } \\
\text { point in history } \\
\text { In } \\
\text { In this subject students will } \\
\text { examine Brazil's history, } \\
\text { development and vibrant }\end{array}$ & $\begin{array}{l}\text { This course will explore how } \\
\text { these cultural practices are } \\
\text { bases on what is called the } \\
\text { colonial wound and as a } \\
\text { result of this contested nature } \\
\text { have built in a corpus of } \\
\text { discourses which question } \\
\text { and challenge hegemonic } \\
\text { cultural productions making } \\
\text { emergent the darker side of } \\
\text { European Modernity, and in } \\
\text { doing so they bring further } \\
\text { emergent new and } \\
\text { challenging aesthetic forms } \\
\text { 91 } \\
\text { The course looks at literary } \\
\text { and artistic representations of } \\
\text { key "rebellious" historical } \\
\text { moments that sought and } \\
\text { continue to seek change and } \\
\text { social justice, especially in } \\
\text { terms of class, ethnicity, race, } \\
\text { gender, sexual practices, } \\
\text { environmental issues, } \\
\text { regional versus globalising } \\
\text { programmes, neoliberal and }\end{array}$ & $\begin{array}{l}\text { They will gain an insight into } \\
\text { cultural diversity of Latin } \\
\text { American societies and } \\
\text { acquire analytical tools for } \\
\text { studying and understanding a } \\
\text { wide variety of topics } \\
\text { associated with political } \\
\text { structure and agency in the } \\
\text { continent. } \\
\text { The course looks at literary } \\
\text { and artistic representations of } \\
\text { key "rebellious" historical } \\
\text { moments that sought and } \\
\text { continue to seek change and } \\
\text { social justice, especially in } \\
\text { terms of class, ethnicity, race, } \\
\text { gender, sexual practices, } \\
\text { environmental issues, } \\
\text { regional versus globalising } \\
\text { programmes, neoliberal and } \\
\text { neo-colonial trends, among } \\
\text { others. }{ }^{60} \\
\text { It will discuss questions } \\
\text { related to centre/periphery, } \\
\text { appropriation/rewriting, and }\end{array}$ \\
\hline
\end{tabular}




\begin{tabular}{|c|c|c|c|}
\hline $\begin{array}{l}\text { conditionings. }{ }^{100} \\
\text { We will also read great } \\
\text { adventure narratives of } \\
\text { "discovery" and piracy, such } \\
\text { as Shipwrecked, and study } \\
\text { the construction of national } \\
\text { myths through novels that } \\
\text { portray key moments leading } \\
\text { to the independence of Latin } \\
\text { American countries. }{ }^{58} \\
\text { The unit may develop } \\
\text { undercurrent theoretical } \\
\text { frames within the discussion } \\
\text { of these classics, such as } \\
\text { "history on film" or the } \\
\text { reinvention of history in } \\
\text { contemporary art. }{ }^{8} \text {. }\end{array}$ & $\begin{array}{l}\text { culture from prior to the } \\
\text { conquest in } 1500 \text { to the } \\
\text { present day. }{ }^{54} \\
\text { This course is an introduction } \\
\text { to the several factors that } \\
\text { shape the diverse cultures of } \\
\text { Latin America, including the } \\
\text { native peoples of the } \\
\text { continent, the impact of } \\
\text { European conquistadors and } \\
\text { colonizers, the ideals of } \\
\text { independence, and the } \\
\text { contemporary continental } \\
\text { order under the strong } \\
\text { influence of the US. }{ }^{96} \\
\\
\text { Nos enfocamos como estos } \\
\text { dos temas han forjado los } \\
\text { debates sobre América Latina } \\
\text { durante el tiempo; y cómo } \\
\text { éste ha sido articulados en las } \\
\text { artes y en pensamiento. Estos } \\
\text { son problemas que han } \\
\text { motivado una serie de } \\
\text { interrogantes y } \\
\text { problemáticas: } ¿ \text { De dónde } \\
\text { venimos? ¿Cuáles son los } \\
\text { fundamentos de la(s) } \\
\text { identidad(es) } \\
\text { latinoamericanas? ¿Adónde } \\
\text { vamos? ¿Hay un componente } \\
\text { indígena? ¿Venimos sólo de } \\
\text { Europa? }{ }^{91} \\
\text { European, North American } \\
\text { and Australasian travellers. }{ }^{94}\end{array}$ & $\begin{array}{l}\text { neo-colonial trends, among } \\
\text { others. }{ }^{60} \\
\text { The subject examines Latin } \\
\text { American responses to } \\
\text { globalisation and } \\
\text { engagement with } \\
\text { international institutions. }{ }^{88} \\
\text { The subject links } \\
\text { contemporary Latin } \\
\text { American and US Latino } \\
\text { peoples and cultures to } \\
\text { broader processes of } \\
\text { transnationalisation, } \\
\text { globalisation and } \\
\text { transculturation. }{ }^{103}\end{array}$ & 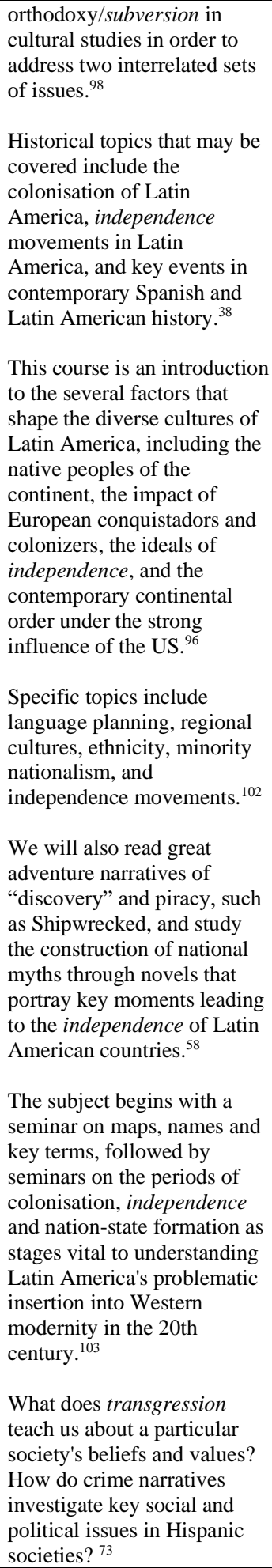 \\
\hline
\end{tabular}

This suggests that the course descriptions from Spanish and Latin American departments in Australian universities are not attempting to entirely disassociate from modernist, colonial configurations of history. Instead, the lexical terms present in course descriptions attend to a decolonial response-ability to visibly foreground an ethico-ontoepistemology grounded in the history of an imagined, colonised and rebelling Latin America. In other words, the discursive practices of historical acceptance constitute 
phenomena in the course descriptions; these phenomena highlight the inseparability of intra-acting ${ }^{65}$ components - coloniality and decoloniality - making space for political change, new forms of identity and community, or ch'ixi.

However, these lexical terms do not appear in course descriptions from every university in the study nor at every level. Seven of the nineteen universities mentioned these terms, and all terms were included in second- or third-year course descriptions of which the majority were electives. Although compulsory and first-year course descriptions, that are primarily grammar and vocabulary-based courses, did tend to make mention of cultural diversity - these appear ahistorically. They were not clearly linked to an exploration of the historical conditions contributing to this diversity. Hence, given the high attrition rates in Spanish and Latin American studies, and the status of the units containing decolonial themes as electives, it is unclear if large cohorts of students are exposed to this way of thinking despite its clear presence in the departments. On the other hand, it is possible that educators are discussing historical acceptance with students despite its absence in some course descriptions. Yet this absence points to a need for the underlying decolonial ethico-onto-epistemology seen in second- and third-year course descriptions to be visibilised in compulsory and first-year courses and for Spanish and Latin American studies departments to consider the ways in which this could be incorporated as part of departmental pedagogical philosophy and praxis. This suggests that these departments have a response-ability to offer decolonial options for their entire student cohort.

\section{Theme Two: Language diversity}

Language diversity is an additional theme that has been highlighted in a number of course descriptions from Spanish and Latin American studies departments. Language diversity is often tied to notions of linguistic diversity that has been critiqued for conceiving of a singular phenomenon in which discrete languages ${ }^{66}$ are positioned as rights-based or as resources meaning their value as more-than resources is not recognised ${ }^{67}$. Conversely, the course descriptions visibilise the multiple ways in which Spanish differs/diffracts.

Numerous course descriptions recognised language diversity in relation to Spanish by referring to: linguistic diversity ${ }^{38}$, influence of other languages on Spanish $^{55}$, literary diversity ${ }^{99}$. This can be seen to disrupt the coloniality of languaging ${ }^{68}$ as described by Gabriela Veronelli ${ }^{107}$ : conceptualising language as a grammatical entity 
for the purpose of teaching, learning and promoting civility (as opposed to barbarity) resulting in the racialisation and the denial of the humanity of those people without a grammatically informed language for the same purposes. She further explains how monolanguaging as a 'communicative practice between people who perceive themselves as having a language in the full sense, and the animal like beings who are assumed to have no language but who can be trained to understand the former well enough to be able to follow their orders and do what they want ${ }^{69}$. In addition, Maseko and Vale discuss the ways in which multilingualism is perceived as a threat to those who do not understand other languages leading to a preference for monolingualism as a source of power through language ${ }^{64}$. Therefore, monolanguaging limits not only what and how languaging can occur but also who has agency, power and voice in languaging interactions. Silvia Rivera Cusicanqui considers the reappropriation of bilingualism as a decolonising practice as necessary for the 'other' to gain agency as producers of knowledge $\mathrm{e}^{80}$.

Further examples of language diversity in the course descriptions can be understood via the textual synonymy. Textual synonymy refers to the use of synonyms in and between texts. Fairclough ${ }^{70}$ notes that whilst texts may include similar vocabulary (synonyms), the ways in which they use this vocabulary (these synonyms) may differ. Therefore, differences in the textual synonymy in the course descriptions showcase how Spanish is positioned as heterogenous through the diffractive semantic relationships between key lexical terms in the texts. An examination of collocations, the words preceding or proceeding focus words, is one strategy for analysing these semantic relationships and textual synonymy.

Collocates preceding the focus word languages (pluralised) in the course descriptions make clear the multiplicity of languages in Latin America by referring to Indigenous $^{11 ; 38}$ and Amerindian languages ${ }^{11}$ whereas the inclusion of the collocations majority and minority languages ${ }^{55}$, multilingual (nature of) Spanish ${ }^{11}$, and Spanglish version $^{109}$ (see Table 3) acknowledge the presence of plurilingualism. Veronelli, drawing on Maturana's concept of languaging, presents the argument that an acknowledgement of the multiplicity of other languages entangled with Spanish and the plurilingual practices of Spanish speakers constitutes an epistemic shift. This shift recognises the on-going, changing nature of languaging (rather than language(s) as a static object(s)). Hence, by visibilising the fluidity of Spanish languaging in course descriptions, Spanish and Latin American studies departments (re)present Spanish as more than a monolithic, singular language as conceived by the coloniality of languaging. This engages in a form of 
'epistemic disobedience' ${ }^{71}$ by imagining languaging differently. In doing so, they also embody their response-ability to students and the languaging practices of AbyaYala to foreground the antagonistic presence of colonial and Indigenous languages as everevolving in a manner reminiscent of un mundo ch'ixi.

Table 3: Proceeding and preceding collocates and textual synonymy from focus words (language/s) in course descriptions from Spanish and Latin American studies departments from eight of the nineteen universities.

Topics addressed include: regional linguistic differences, majority and minority languages, the influence of other languages, politeness and forms of address, and language planning. ${ }^{55}$

A snap-shot approach to topical issues in the Hispanic world is used to help you to gain a better understanding of Hispanic peoples, their language and their rich cultures. ${ }^{43}$

The main focus is on diverse outcomes of language contact with Amerindian languages in its historical and contemporary context. ${ }^{43}$

The area of linguistic diversity may include issues such as the past and present of Spain's four official languages; indigenous languages in Latin America. ${ }^{38}$

Different topics related to Hispanic Linguistics are covered, to help students develop linguistic awareness and thereby enhance their oral, written and comprehension skills. ${ }^{9}$

Contemporary Spain is a very diverse country with several distinct cultural and linguistic groups. ${ }^{102}$

It focuses on such topics as Spanglish, dictatorships, gender and other relevant areas. ${ }^{43}$

Particular attention will be paid to the dialectal geography of the Hispanic world, and to the problems faced by the language today, with particular reference to its 'Spanglish' version in emigre communities in the United States and Australia, and to information technology. ${ }^{109}$

Based on in-depth case studies and individual research projects, students will be introduced to methodologies in studying dialectal variability and will gain first-hand experience at empirical linguistic analysis. ${ }^{11}$

.... and the similarities and differences between the varieties of Spanish spoken in Spain and in Latin America. ${ }^{38}$

A sophisticated range of authentic material, including films, documentaries, testimonies and music with lyrics, with regional and social variants, and specific registers... ${ }^{104}$

The unit introduces the students to socio-linguistic aspects of the use of Spanish such as dialectal variations and bilingualism. ${ }^{12}$

For students whose first language is not Spanish, covers special areas of difficulty in Spanish language, many of which result from geographical or cultural variations \& are problematic even for native speakers. $^{95}$

This course introduces students to the multilingual nature of the Spanish-speaking world... ${ }^{11}$

Students will explore and experience the cultural and literary diversity of the Hispanic world by reading, discussing, commenting, and analysing in detail a variety of literary genres. ${ }^{99}$ 


\section{Theme Three: Gender and sexuality}

Sandra Harding reminds us that 'gender and sexuality considerations should not be regarded as an optional addition to analyses of colonialism; they are an intrinsic element of such phenomena' ${ }^{72}$. Continuing the decolonial turn to acknowledge the diverse ways of being promoted in the course descriptions, I sought examples that visibilised gender and sexuality. The course descriptions did so through instances of intertextuality. Intertextuality is the processes of inserting texts of the past, and thereby history, into discourse resulting in cultural and social transformation ${ }^{73}$. These insertions may be explicit, indicated by quotation marks, or implicit, based on presumed background knowledge $^{74}$. Social and cultural transformations, thus, manifest in the alteration of the colonial ethico-onto-epistemology underlying world language study whereby Christianity is disempowered from its role controlling sexuality and gender ${ }^{75}$. Therefore, themes from external texts subverting Christian notions of gender and sexuality (purity, heterosexuality, sex-based gender roles) as well as the visibilisation of women's names in the course descriptions indicate the ways in which Spanish and Latin American studies departments resist the coloniality of being/gender.

References, such as art $^{97}$, poetry ${ }^{59}$, rap $^{59}$, television $^{59}$, food texts ${ }^{87}$, literature $^{8 ; 59 ; 86}$, legislation ${ }^{89}$,paintings ${ }^{97}$ and cinema $^{39 ; 90}$ to a wide variety of texts (italicised in Table 3 ) highlight sites of resistance and oppression. Although other critical discourses analyses may seek to uncover specific lines from the poetry, literature or legislation as evidence of intertextuality, their presence implicitly suggests particular ideological positionings when combined with thematic markers of gender, sexuality and female protagonists (in bold in Table 4) both inside and outside the academy. To illustrate, phrases such as 'to explore the expression of Spanish-speaking women and men against the power of dominant gender constructions' ${ }^{59}$, 'construction of gender' ${ }^{39}$, 'prescription and redescription of gender $^{\prime 87}$, 'gender violence...new masculinities' ${ }^{89}$, 'interrogate issues of...gender ${ }^{\text {'73 }}$ and 'post-colonial feminisms ${ }^{89}$ decentre the heteropatriarchal principles and make space for alternative ways of being/knowing/doing gender and sexuality.

Table 4: Thematic intertextual relations of gender/sexuality (in bold) and associated texts (in italics) in seven of the nineteen Spanish and Latin American studies departments in Australian universities. 
a variety of genres (poetry, rap, film, television and theatre) to explore the expression of Spanish-speaking women and men against the power of dominant gender constructions ${ }^{59}$

The course looks at literary and artistic representations of key 'rebellious' historical moments that sought and continue to change ....gender, sexual practices $^{59}$

This course aims to explore Hispanic history through its literary and cultural representations in comparative perspectives (cross-cultural, critical discourse analysis, gendered, memory, etc.). ${ }^{8}$ Themes include the social and political construction of ethnic identities, indigenous manifestations, decolonization, religion, dictatorships, democratization and the changing roles of women. ${ }^{8}$

Cinema from the Spanish-speaking World ...consider themes such as sexuality ${ }^{90}$

We will debate....the scarcity of female directors and the topics women bring to the screen $^{90}$

The paintings of Frida Kahlo will also be examined within this context. ${ }^{97}$

Examples will be drawn from a wide range of cultural areas, including literature, film, art, and music, and will include work by figures such as García Lorca, Pedro Almodóvar, Pablo Neruda, Isabel Allende, Gabriel García Márquez, Salvador Dalí, and Frida Kahlo. ${ }^{37}$

Some of the authors to be included for study and analysis are Gabriel Garcia Marquez, Jorge Luis Borges, Alejo Carpentier and Gioconda Belli. ${ }^{86}$

Authors and film-makers who may be covered in this topic include, García Lorca, Miguel Delibes, Martí Gaite, Rosa Montero, Carlos Saura, Mario Camus, Pedro Almodóvar and Icíar Bollaín. ${ }^{40}$

We will debate the ways in which Latin American cinema differentiates itself from Hollywood, the scarcity of female directors and the topics women bring to the screen, among other issues. ${ }^{10}$

We will consider themes such as homosexuality, political dissidence, violence and 'otherness'. ${ }^{10}$

Films and literary texts will examine key issues in Latin American cinema such as questions of violence and power, race and ethnicity, eroticism and the construction of gender and sexuality, the representation of border issues, migration, urban life, and youth culture, social change. ${ }^{39}$

Authors and film-makers who may be covered in this topic are, among others, Roberto Bolano, Isabel Allende, Gabriel García Márquez, Jorge Luis Borges, Julio Cortázar, Pablo Urbanyi, Elena Poniatowska, Angeles Mastretta and Margo Glantz.; Enrique Fabián Bielinsky, Marcelo Pineyro, Jorge Gaggero, Leonardo Di Cesare. Pablo Trapero, Eliseo Subiela and Carlos Sorín. ${ }^{39}$

In this subject such issues are explored in relation to their representation in cultural texts - including fiction literature, film and TV. Major themes to be explored include gender violence, gay marriage legislation, gender reassignment legislation, post-colonial feminisms, new masculinities, and sexism in language. ${ }^{89}$

These range from the prescription and re-description of gender roles to processes of modernisation, from national renewal to questions of national boundaries... Academic skills are enhanced through learning how to write scholarly essays in Spanish and to do close readings of a variety of food texts and scholarly and journalistic articles. ${ }^{87}$

This unit examines fiction and film from Spain and Latin America, and is concerned with understanding the ways in which crime and detective narratives, some of the most popular forms of fiction and film today, investigate and interrogate issues of national identity, gender, sexuality, ethnicity and historical justice in Hispanic societies. $^{73}$

Moreover, the pluralisation of terms including 'feminisms' ${ }^{89}$, 'gender constructions ${ }^{59}$, 'masculinities ${ }^{59}$, 'issues... of gender', ${ }^{39}$ and the terms 'prescription 
and redescription" ${ }^{87}$, and 'interrogate ${ }^{73}$ advocate for what Sandra Harding has referred to as the 'otherwise' of gender ${ }^{76}$ by challenging essentialist or dichotomist views of gender. The 'otherwise' of gender, in line with Gloria Anzaldúa's borderlands and Silvia Rivera Cusicanqui's ch'ixi concept, positions gender beyond traditional masculinity and femininity; rather than associate gender with anatomy, it is based on roles, and ways of being/knowing/doing in the world where gender fluctuates on an open, dynamic and unheirarchical equilibrium. In this way, the course descriptions featuring these terms put forth a diffractive and nuanced understanding of gender: one that also avoids limiting Indigenous gender to a static past incapable of forging a new destiny by seeing gender as part of a reciprocal and antagonistic process of Indigenous modernity whereby past, present and future racialised/entangled/dominant and 'otherwise' gender relations are acknowledged.

Seven of the Spanish and Latin American studies departments have course descriptions that mention women by name: Frida Kahlo ${ }^{37 ; 97}$, Isabel Allende ${ }^{37 ; 39}$, Gioconda Belli $^{86}$, Elena Peniatowska ${ }^{39}$, Angeles Mastretta ${ }^{39}$, Margo Glantz $^{39}$, Martí Gaite $^{40}$, Rosa Montero ${ }^{40}$, Icíar Bollaín ${ }^{40}$ (see Table 4) or noted the diverse roles of women: 'changing roles of women', and 'female directors and the topics women bring to the screen ${ }^{\prime 10}$ (see Table 4). These examples could be understood as a decolonial turn towards voice and agency for women, or following the line of argument from Amadiume, a reclamation of the masculine social roles accessible to women in traditional societies ${ }^{77}$; however, it should be recognised that all the women's names appear in lists in which they are outnumbered by their male counterparts, Indigenous women are missing in favour of more well-known authors and artists, and that the coloniality of gender calls for an analysis of the intersection of race, class, capitalism and gender ${ }^{78}$, including between men $^{79}$, and this is not mentioned in all course descriptions.

\section{Conclusion}

In this paper, I have analysed the course descriptions from nineteen Spanish and Latin American studies departments in Australian universities. Course descriptions operate as promotional material and curriculum documents meaning the discourses and ideologies they communicate have the power to influence those within the university and outside of it. Yet the institutionalised genre and neoliberal market in 
which university course descriptions are situated has systematically excluded certain ways of knowing/being and doing from tertiary language education whereby linguistic perfection rather than more ethico-onto-epistemological responseabilities was attended to. This is not to deny the importance of named languages and standardisation for particular social and political functions including language preservation and revitalisation efforts. Nor is it to deny that teaching and learning a standardised 'linguistic form' may even make clear the external separation of languages in order for language hierarchies to be more carefully dismantled and equalised. However, it does question how and what we teach and learn regarding Spanish as a world language in higher education and why this matters, particularly amidst global cries for decolonising education.

Using critical discourse analysis, informed by decolonial theory, I have attempted to rethink the traditional, Eurocentric approach to such analyses by searching for linguistic markers of decolonial themes. An overarching decolonial theme I sought drew on Silvia Rivera Cusicanqui's theorising of un mundo ch 'ixi: a world of juxtaposition in which opposites antagonise and reciprocate the other in a muddling that does not result in complete mixing; it is a world of an alternate space ${ }^{80}-$ the borderlands.

My analysis of the course descriptions suggested an array of decolonial themes. The most prominent themes were included in this paper and included: historical acceptance, language diversity and gender and sexuality. I see themes resonating with the concept of un mundo ch'ixi in that they are juxtaposing decolonial course content, Indigenous knowledges and oftentimes radical, nuanced and provocative topics against the conservative, neoliberal policies that universities put in place to the avoid economic repercussions of pushing academic boundaries. Or rather, I see ch'ixi in the course descriptions as Anders Burman suggests: ontological disobedience ${ }^{17}$. That is not to say that other themes were not present. For example, a limited number of course descriptions made specific mention of environmental issues and consumerism; however, there were insufficient examples to indicate a decolonial turn in Spanish and Latin American studies departments in general as more prominent themes may suggest.

However, I wish to end by speculating about some of the ways in which research inspired by and searching for un mundo ch 'ixi might further turn our languaging practices toward the decolonial. I suggest that by focusing on the valuable and challenging work that Spanish and Latin American studies departments are doing to visibilise unfixed, fluid and dynamic understandings of gender, sexuality and language (rather than critique 
potentially problematic content) we can antagonise with kindness and reciprocate with attendances to our ethico-onto-epistemological response-abilities. I suggest that the response-abilities, of not only Spanish and Latin American studies departments in Australia but all language departments, include a commitment to challenge our own ethico-onto-epistemological positionings. This involves inviting alternative ways of thinking, doing and being into introductory language courses. It is not a process of rewriting curriculum, reinventing content or radical retraining programs for educators. Instead, it is a shift in the ethico-onto-epistemology underlying languaging practices in Australian universities. It is engaging in dialogue about and with existing content from decolonial (and other critical theoretical) perspectives. In this way, we may work to decolonise our own minds by taking part in the reciprocal and antagonistic questioning that un mundo ch'ixi tempts.

\section{Conflict of interest}

No potential conflict of interest was reported by the author.

Note 


\section{Bibliography}

Abril, N.G.P., "Análisis crítico del discurso: Conceptualización y desarrollo."

Cuadernos de Lingüística Hispánica, no. 19 (2012): 41-62.

Abril, N.G.P. Cómo hacer análisis crítico del discurso: una perspectiva latinoamericana: Frasis, 2007.

Ahmed, A.K., "The Rise of Fallism:\# RhodesMustFall and the Movement to

Decolonize the University," Doctoral, Columbia University, 2019.

Aman, R., "Colonial differences in intercultural education: On interculturality in the Andes and the decolonization of intercultural dialogue." Comparative Education Review 61, no. 1 (2017): 103-S20, doi:10.1086/690459.

Aman, R. Decolonising intercultural education : colonial differences, the geopolitics of knowledge, and inter-epistemic dialogue. Abingdon, Oxon: Routledge, an imprint of the Taylor \& Francis Group, an Informa business, 2018.

Amorati, R., "Making Languages Marketable: An Analysis of a Promotional Brochure for Prospective Students in an Australian Tertiary Institution." Language Learning in Higher Education 8, no. 2 (2018): 313-31, doi:10.1515/cercles-2018-0018.

Anzaldúa, G. Borderlands : The New Mestiza $=$ La Frontera . San Francisco: Aunt Lute Books, 1987.

Australian National University, "Advanced Spanish topics in Language and Culture SPAN3030." Accessed 6th June, 2019.

https://programsandcourses.anu.edu.au/course/SPAN3030.

Australian National University, "Advanced Spanish Topics in Language and Linguistic SPAN 3031." Accessed 6th June, 2019.

https://programsandcourses.anu.edu.au/2020/course/SPAN3031.

Australian National University, "Cinema from the Spanish speaking world SPAN2107." Accessed 6th June, 2019.

https://programsandcourses.anu.edu.au/2019/course/SPAN2107.

Australian National University, "Multilingualism and Indigenous peoples in the Americas (SPN2604)." Accessed 6th June, 2019.

https://programsandcourses.anu.edu.au/course/SPAN2604.

Australian National University, "Sounds of Spanish SPAN2601." Accessed 6th June, 2019. https://programsandcourses.anu.edu.au/course/span2601.

Barad, K. Meeting the universe halfway quantum physics and the entanglement of matter and meaning. Durham: Duke University Press, 2007.

Bolívar, A., "A change in focus: from texts in contexts to people in events." Journal of Multicultural Discourses 5, no. 3 (2010): 213-25.

Bolivar, A. and F.D. de Erlich, "La práctica del análisis del discurso en contextos políticos polarizados. Una reflexión crítica." Revista latinoamericana de estudios del discurso 11, no. 1 (2011): 9-30.

Bonnell, A.G., "The Ramsay Centre and 'Western Civilisation': An attempt at historical perspective A reaction to Martin Davies' paper ". Australian Universities' Review 61, no. 2 (2019): 65.

Burman, A., "Damnés realities and ontological disobedience : Notes on the coloniality of reality in higher education in the Bolivian Andes and beyond," Chap., In

Decolonizing the westernized university : Interventions in philosophy of education from within and without - interventions in philosophy of education from within and without, edited by Grosfoguel, R., R. Hernández and E. Rosen Velásquez, 71-94. Maryland, USA: Lexington Books, 2016. 
Burman, A., "The Political Ontology of Climate Change : Moral Meteorology, Climate Justice, and the Coloniality of Reality in the Bolivian Andes." Journal Of Political Ecology 24 (2017): 921-21.

Casanova, M.V., "Los criterios de corrección en las gramáticas de la Real Academia Española." Boletín de la Real Academia Española 97, no. 316 (2018): 581-631.

Castro-Gómez, S., "Decolonizar la universidad. La hybris del punto cero y el diálogo de saberes." El giro decolonial. Reflexiones para una diversidad epistémica más allá del capitalismo global (2007): 79-91.

Chiapello, E. and N. Fairclough, "Understanding the New Management Ideology: A Transdisciplinary Contribution from Critical Discourse Analysis and New Sociology of Capitalism." Discourse \& society 13, no. 2 (2002): 185-208.

Clyne, M., "The Monolingual Mindset As An Impediment To The Development Of Plurilingual Potential In Australia." Sociolinguistic Studies 2, no. 3 (2008): 347-66. Clyne, M., "Trapped in a monolingual mindset." Principal Matters, no. 59 (2004): 1820.

Cuffari, E.C., E. Di Paolo, and H. De Jaegher, "From Participatory Sense-Making to Language: There and Back Again." Phenomenology and the Cognitive Sciences 14, no. 4 (2015): 1089-125, doi:10.1007/s11097-014-9404-9.

Cupples, J., "Introduction: Coloniality resurgent, coloniality interrupted," Chap., In Unsettling Eurocentrism in the Westernized University, edited by Cupples, J. and R. Grosfoguel, 1-22: Routledge, 2019.

Cupples, J. and R. Grosfoguel. Unsettling Eurocentrism in the Westernized University. 1 ed: Routledge, 2019.

Cusicanqui, S.R., "Ch'ixinakax utxiwa: A reflection on the practices and discourses of decolonization." Language, Culture, and Society 1, no. 1 (2019): 106-19, doi:10.1215/00382876-1472612.

Cusicanqui, S.R., "Ch’hixinakax utxiwa: Una reflexión sobre prácticas y discursos descolonizadores," Chap., In Modernidad y pensamiento descolonizador. Memoria del Seminario Internacional edited by Yupi, M., 3-16. La Paz, Bolivia: U-PIEB-IFEA, 2006.

Daley, P., "Statues are not history. Here are six in Australia that need rethinking," Chap., In The Guardian2017.

de Sousa Santos, B. Justicia entre saberes: Epistemologías del Sur contra el epistemicidio. Madrid, Spain: Ediciones Morata, 2018.

Demuro, E. and L. Gurney, "Mapping language, culture, ideology: Rethinking language in foreign language instruction." Language and Intercultural Communication 18, no. 3 (2018): 287-99, doi:10.1080/14708477.2018.1444621.

Diaz, A.R., "Intercultural Competence through Language Education in Australian Higher Education: Mission (Im)possible?," Type presented at the Languages and Cultures Network for Australian Universities Colloquium, Melbourne, Australia, 2011. Escobar, A., "América Latina en una encrucijada ¿modernizaciones alternativas, postliberalismo o posdesarrollo?." Revista Controversia 197, no. 1 (2011): 9-61. Fairclough, N. Analysing Discourse : Textual Analysis for Social Research. London: Routledge, 2003.

Fairclough, N. Critical discourse analysis : The critical study of language. 2 nd ed. Harlow: Longman, 2010.

Fairclough, N., "Intertextuality in Critical Discourse Analysis." Linguistics and Education 4, no. 34 (1992): 269-93.

Flinders University, "An Introduction to Spanish and Latin American Cultures SPAN2212." Accessed 6th June, 2019. 
Flinders University, "SPAN2211 Keys to the Spanish and Latin American Worlds." Accessed 6th June, 2019.

https://www.flinders.edu.au/webapps/stusys/index.cfm/topic/main?subj=SPAN\&numb= 2211.

Flinders University, "SPAN3211 Latin American History and Culture Through Film and Literature." Accessed 6th June, 2019.

https://www.flinders.edu.au/webapps/stusys/index.cfm/topic/main?numb=3211\&subj=S PAN\&year $=2020 \&$ fees $=Y$.

Flinders University, "SPAN3311 Contemporary Spanish History and Culture Through Film and Literature ". Accessed 6th June, 2019.

https://www.flinders.edu.au/topic?numb=3311\&subj=SPAN\&year=2020\&fees=Y.

Flores, N., "A tale of two visions: Hegemonic whiteness and bilingual education."

Educational Policy 30, no. 1 (2016): 13-38, doi:10.1177/0895904815616482.

George, A., "A Philosopher with a Plan: Reflections on Ifi Amadiume's Male

Daughters, Female Husbands." Journal of West African History 3, no. 2 (2017): 124-30, doi:10.14321/jwestafrihist.3.2.0124.

Griffith University, "A Window into Hispanic Cultures." Accessed 6th June, 2019.

https://www.griffith.edu.au/study/courses/3086LHS.

Grosfoguel, R., "La descolonización de la economía política y los estudios

postcoloniales: transmodernidad, pensamiento fronterizo y colonialidad global.." Tabula

Rosa 4 (2006): 17-46.

Haraway, D.J. Staying with the Trouble : Making Kin in the Chthulucene. London,

England Duke University Press, 2016.

Harding, S., "Latin American Decolonial Studies: Feminist Issues." Feminist Studies 43, no. 3 (2017): 624-36, doi:10.15767/feministstudies.43.3.0624.

Heugh, K. and C. Stroud, "Diversities, affinities and diasporas: A Southern lens and methodology for understanding multilingualisms." Current Issues in Language

Planning 20, no. 1 (2019): 1-15, doi:10.1080/14664208.2018.1507543.

Hodes, C., "Gender, race and justification: The value of critical discourse analysis

(CDA) in contemporary settler colonial contexts." Journal of International Women's

Studies 19, no. 3 (2018): 71-91.

Holliday, A., "Native-speakerism." ELT Journal 60, no. 4 (2006): 385-87,

doi:10.1093/elt/ccl030.

Houghton, S.A. and K. Hashimoto. Towards Post-native-speakerism : Dynamics and

Shifts. Singapore: Springer, 2018.

Jones, A., "The limits of cross-cultural dialogue: Pedagogy, desire, and absolution in the classroom." Educational theory 49, no. 3 (1999): 299,

doi:https://search.proquest.com/docview/214142152?accountid=14723.

Kaneva, D., J. Bishop, and N.E. Whitelaw, "Initiating decolonial praxis: childhood studies curricula in an English university." Third World Thematics: A TWQ Journal (2020): 1-18, doi:10.1080/23802014.2020.1762511.

La Trobe University, "Conquest of the Americas: Aztecs, Maya and Incas LAS3CAM."

Accessed 6th June, 2019. https://www.latrobe.edu.au/students/your-

course/subjects/current/las3cam-conquest-of-the-americas.

La Trobe University, "LAS2BRZ Brazil: History, development, culture and the Amazon." Accessed 6th June, 2019. https://www.latrobe.edu.au/students/yourcourse/subjects/current/las2brz-brazil.

La Trobe University, "Spanish 7 Language and society in the Hispanic world SPA4007." Accessed 6th June, 2019. https://www.latrobe.edu.au/students/yourcourse/subjects/current/spa4007-spanish-7. 
Lander, E., ¿¿Conocimiento para qué? ¿Conocimiento para quién?

Reflexiones sobre la universidad y la geopolítica de los saberes hegemónicos " Chap., In La reestructuración de las ciencias sociales en América Latina, edited by CastroGómez, S. Bogota, Colombia: Centro Editorial Javeriano, 2000.

Lugones, M., "Hacia un feminismo descolonial." La Manzana de la Discordia 6, no. 2 (2010): 105-17, doi:10.25100/lamanzanadeladiscordia.v6i2.1504

Macquarie University, "Advanced Spanish III - SPN403." Accessed 6th June, 2019. http://handbook.mq.edu.au/2019/Units/UGUnit/SPN403.

Macquarie University, "Passion and repression - SPN210." Accessed 6th June, 2019. http://handbook.mq.edu.au/2019/Units/UGUnit/SPN210.

Macquarie University, "Rebellion and Change - SPN325." Accessed 6th June, 2019. http://handbook.mq.edu.au/2019/Units/UGUnit/SPN325.

Maddison, S. Conflict Transformation and Reconciliation: Multi-level Challenges in Deeply Divided Societies: Taylor and Francis, 2015.

Makoni, S.B., "An integrationist perspective on colonial linguistics." Language

Sciences 35, no. 1 (2013): 87-96, doi:10.1016/j.langsci.2012.06.001.

Maldonado-Torres, N., "Sobre la colonialidad del ser: contribuciones al desarrollo de un concepto." El giro decolonial. Reflexiones para una diversidad epistémica más allá del capitalismo global (2007): 127-47.

Maseko, P. and P. Vale, "The struggles over African languages." Arts and Humanities in Higher Education 15, no. 1 (2016): 79-93, doi:10.1177/1474022215613605.

Maturana, H., "Ontology of Observing: The Biological Foundations of Self

Consciousness and the Physical Domain of Existence," Type presented at the Texts in Cybernetic Theory: An In-depth Exploration of the Thought of Humberto Maturana, William T. Powers, and Ernst von Glasersfeld, CA, United States, 1988.

Maturana, H.R. and F.J. Varela. Autopoiesis and Cognition: The Realization of the Living. Vol. 42: Springer Science \& Business Media, 1991.

Mendizabal, I.R., "Analisis del discurso en Latinoamerica: un estado de arte/Discourse analysis in Latin America: a state of art/Analise do discurso na America Latina: um estado da arte." Chasqui: Revista Latinoamericana de Comunicacion, no. 139 (2018): 15.

Mignolo, W. The Darker Side of Western Modernity Global Futures, Decolonial Options: Durham : Duke University Press, 2011.

Mignolo, W. Historias locales/diseños globales: colonialidad, conocimientos subalternos y pensamiento fronterizo. Madrid, Spain: Ediciones Akal, 2003. Mignolo, W., "La idea de América Latina (la derecha, la izquierda y la opción decolonial)." Crítica y Emancipación 2 (2009): 251-76.

Mignolo, W. and C.E. Walsh. On Decoloniality: Concepts, Analytics, and Praxis, 2018. Mignolo, W.D., "Introduction: Coloniality of Power and De-Colonial Thinking." Cultural Studies 21, no. 2-3 (2007): 155-67, doi:10.1080/09502380601162498. Monash University, "ATS3867 - Crime fiction and film in Hispanic cultures." Accessed 6th June, 2019. https://www3.monash.edu/pubs/2019handbooks/units/ATS3867.html. Morreira, S., J. Taru, and C. Truyts, "Place and pedagogy: using space and materiality in teaching social science in Southern Africa." Third World Thematics: A TWQ Journal (2020): 1-17, doi:10.1080/23802014.2020.1747944.

Murris, K. and V. Bozalek, "Diffraction and response-able reading of texts: the relational ontologies of Barad and Deleuze." International Journal of Qualitative Studies in Education (2019): 1-15, doi:10.1080/09518398.2019.1609122. 
Pardo, L., "Latin-American discourse studies: state of the art and new perspectives." Journal of Multilingual Discourses 5, no. 3 (2010): 183-92, doi:10.1080/17447143.2010.508526.

Quijano, A., "Colonialidad y modernidad/racionalidad." Perú Indígena 13, no. 29 (1992): 11-20.

Reisigl, M. and R. Wodak. Discourse and discrimination rhetorics of racism and antisemitism. London: Routledge, 2001.

Resende, V.D.M., "Decolonizing critical discourse studies: For a Latin American perspective." Critical Discourse Studies (2018): 1-17, doi:10.1080/17405904.2018.1490654.

Rivera Cusicanqui, S., "Ch'ixinakax Utxiwa: A Reflection on the Practices and Discourses of Decolonization." South Atlantic Quarterly 11, no. 1 (2012): 80, doi:10.1215/00382876-1472612.

Rogers, R. An Introduction to Critical Discourse Analysis in Education. 2nd ed. New York: Routledge, 2011.

Skutnabb-Kangas, T., "Language Rights," Chap., In The handbook of bilingual and multilingual education, edited by W.E. Wright, S.B., \& O. García, 185-202. Malden, MA: Wiley-Blackwell, 2015.

Smala, S., J.B. Paz, and B. Lingard, "Languages, Cultural Capital and School Choice: Distinction and Second-Language Immersion Programmes." British Journal of Sociology of Education 34, no. 3 (2013): 373-91, doi:10.1080/01425692.2012.722278. Stein, S. and V. de Oliveira Andreotti, "Higher education and the modern/colonial global imaginary." Cultural Studies $\leftrightarrow$ Critical Methodologies 17, no. 3 (2017): 173-81, doi:10.1177/1532708616672673.

Taylor, S., "Discourse as data : A guide for analysis," Chap., In Discourse as data : A guide for analysis, edited by Wetherell, M., S. Taylor and S. Yates, 5-48. London, England: SAGE in association with Open University Press, 2001.

The University of Adelaide, "SPAN 3006 - Latin American Literature and Society." Accessed 6th June, 2019. https://www.adelaide.edu.au/course-outlines/105372/1/sem$\underline{1 / 2019 / .}$.

The University of Melbourne, "Cooking up the Nation (SPAN20024)." Accessed 6th June, 2019. https://handbook.unimelb.edu.au/subjects/span20024.

The University of Melbourne, "Exploring Latin America (SPAN30021)." Accessed 6th June, 2019. https://handbook.unimelb.edu.au/2019/subjects/span30021.

The University of Melbourne, "Gender in Hispanic Cultures (SPAN30001)." Accessed June 6, 2019. https://handbook.unimelb.edu.au/2019/subjects/span30001.

The University of Melbourne, "Hispanic Film Today (SPAN30017)." Accessed June 6, 2019. https://handbook.unimelb.edu.au/2019/subjects/span30017.

The University of Queensland, "America Latina: el deseo y la realidad (SPAN3390)." Accessed June 6, 2019. https://my.uq.edu.au/programs-

courses/course.html?course code=SPAN3390.

Truckenbrodt, A. and R. Cross, "Getting Two for One: Learning Another Language through CLIL," Chap., In Teaching Young Second Language Learners, 127-44:

Routledge, 2018.

Tuck, E. and K.W. Yang, "Decolonization is Not a Metaphor." Decolonization:

Indigeneity, education \& society 1, no. 1 (2012).

University of New England, "SPAN303 Travellers' Tales: The Invention of Latin

America." Accessed June 6, 2019. https://my.une.edu.au/courses/units/SPAN303. 
University of Queensland, "Advanced Spanish A (SPAN3110)." Accessed June 6, 2019. https://my.uq.edu.au/programs-

courses/course.html? course code=SPAN3110\&year=2020.

University of Queensland, "Cultures of Latin America (LTCS2026)." Accessed June 6, 2019. https://my.uq.edu.au/programs-courses/course.html?course_code=LTCS2026.

University of Queensland, "Imagining Latin America in the 20th Century (LTCS2022)." Accessed June 6, 2019. https://my.uq.edu.au/programs-

courses/course.html?course_code=LTCS2022.

University of Queensland, "Latin American Perspectives (LTCS3000)." Accessed June 6, 2019. https://my.uq.edu.au/programs-courses/course.html? course_code=LTCS3000.

University of Queensland, "Literature en Espanol (SPAN3460)." Accessed June 6, 2019. https://my.uq.edu.au/programs-courses/course.html?course_code=SPAN3460.

University of Sydney, "Citizenship in Spain and Latin America - SPAN2616." Accessed April 18, 2019. https://www.sydney.edu.au/courses/units-of-

study/2020/span/span2616.html.

University of Sydney, "Indigenous Movements in Latin America - SPAN3615."

Accessed April 18, 2020. https://www.sydney.edu.au/courses/units-of-

study/2020/span/span3615.html.

University of Sydney, "Spanish: A Nation of Nations SPAN3624." Accessed April 18, 2020. https://www.sydney.edu.au/courses/units-of-study/2020/span/span3624.html.

University of Technology Sydney, "976502 Contemporary Latin(o) Americas."

Accessed June 6, 2019. https://handbook.uts.edu.au/subjects/976502.html.

van Dijk, T.A., "Discourse Studies and Hermeneutics." Discourse Studies 13, no. 5

(2011): 609-21, doi:10.1177/1461445611412762.

Vergara, S.L., "Indigenous Intellectuals and the Politics of Decolonial Knowledge: New Anti-Colonial Paradigms in Abya Yala." Critical Reviews on Latin American ResearchCROLAR 7, no. 1 (2018).

Veronelli, G., "About the coloniality of language." Universitas Humanística, no. 81 (2016): 33-58, doi:10.11144/Javeriana.uh81.scdl.

Veronelli, G., "La colonialidad del lenguaje y el monolenguajear como práctica lingüística de racialización." Polifonia 26, no. 44 (2019): 146-59.

Warhuus, J. and S. Jones, "Gendered Language, Gendered Choices? Student Responses to Entrepreneurship Education Course Descriptions," (2018).

Western Sydney University, "Spanish 308: Spanish Sociolinguistics." Accessed June 6, 2019. http://handbook.westernsydney.edu.au/hbook/unit.aspx?unit=100158.2.

Wodak, R. and B. Forchtner. The Routledge handbook of language and politics. $1 \mathrm{ed}$ :

Routledge 2017.

Wodak, R. and M. Meyer. Methods of critical discourse analysis. 2nd ed. London:

SAGE, 2009. 